\title{
Practices and policies in child labour: Iessons from Malta
}

Ronald G. Sultana

Faculty of Education, University of Malta

\begin{abstract}
The problem of child labour is widespread in Malta, despite the fact that there is compulsory schooling up to the age of 16 , and even although most of the necessary formal legislative measures to combat the employment of children have been taken. Data is presented in order to provide a clear picture of the extent of the problem, as well as of the general conditions which prevail in the 'twilight economy' in which child workers labour. Economic and socio-cultural reasons which could explain the continuing practice of child labour in Malta are explored, and general policy recommendations made.
\end{abstract}

\section{Introduction.}

The problem of 'child labour' has surfaced and submerged in the eyes of public opinion and policy makers as a 'scourge' and ' $a$ blot on the conscience of the developed and developing countries' (Unesco Courier, 1973, p.7). While the excesses we usually associate with the 19 th century have been curbed through legislative means and the pressure of social and economic transformation, it is quite clear that the practice of child labour is still widespread.

The purpose of this paper is to present original data on the extent of child labour in Malta, ${ }^{1}$ and to situate that data within a context which does justice to the complexity of the issues involved, the international dimensions of the problem, as well as to the legislative and other recommendations made by such bodies as the International Labour Organisation, Unesco, the United Nations Children's Fund, and the AntiSlavery Society in order to promote the rights of children. In this paper I will therefore provide evidence to show that a high percentage of young students from one stream of Malta's secondary school system, namely Trade Schools, ${ }^{2}$ have experienced work on a part-time and/or a full-time basis.

The focus of this paper will be on the conditions under which these students labour in what has been called the "twilight econony" (Finn, 1984). More specifically, this study will first place the problem of child labour in an international context. It will then present a historical, sociological and empirical analysis of the the employment of children in Malta. This case-study, it is argued, is useful in the generation of policy recommendations for combating child labour, and thus provides insights to others engaged in this field. 


\section{Child labour in an international context}

Statistics on the extent of child labour at a national and international level depend on the way 'child' and 'labour' are in fact defined. The Intemational Labour Organisation employs the term 'child' to refer to young persons below the age of completion of compulsory schooling and in any case not less than 15 years. By 'employment', 'work' or 'labour", the ILO refers to to all economic activity done by children, regardless of their formal employment status. ${ }^{3}$

It is important to point out that the ILO does not impose a blanket prohibition on 'child labour' - what it does set out to do is to prohibit the imposition on children of labour which calls for greater physical and mental resources than they normally possess or which interferes with their education and development. It also sets out to regulate the conditions under which these young people may be allowed to work.

If we take into consideration the above clarification regarding the meaning of "child labour", and if we look at the results of statistical surveys carried out by a number of international organisations, it becomes immediately clear that the incidence of children's involvement in industrial and non-industrial work is very high indeed. ILO statistics (Swepston, 1982, p.591) estimate the number of working children under 15 to be 55 million for the world as a whole. However, as Schildkrout $(1980$, p.379) points out, figures such as these are often based on census reports which take only the formal wage sector into account. In fact, a United Nations study (Economic and Social Council, 1981) considers that the figure of 145 million children is much closer to the mark. While the problem is clearly more prevalent in developing countries such as India, Colombia and a number of African nations (Bequele and Boyden, 1988a), it is also present in economically developed countries such as the United States (Bingham, 1990), the United Kingdom (MacLennan, 1980; Finn, 1984; Fyfe, 1989; Lavalette et al., 1990), and New Zealand (Sultana, 1990).

\section{Child labour in Malta: Legislative history}

Child labour in Malta, as in many other countries, has a long history. Prior to the nineteenth century and throughout the slow industrialisation of the Islands, children were an economic asset as unpaid, or underpaid family workers (Busuttil, 1965). Serious attention was first given to the issue of child labour in Malta when the Compulsory Attendance Act fixed the school leaving age at twelve. It was stipulated that these students were to attend school at least $75 \%$ of the time (Sultana, 1992). The Act made it illegal for employers to take on minors during school hours, but this was only binding for children registered in the few State schools then available.

The loopholes of the 1924 Act were addressed in a progressive manner as various ordinances were passed at regular intervals (Borg, 1983). These various ordinances and acts specified not only the age at which children could be employed, but also the length of time they could spend at work. Legislative measures also stipulated the areas of employment which could have a significant negative impact on the health and safety of minors, as well as on their moral and overall development. Regulation was tightened as systems of inspection of industrial and commercial premises were introduced (in 1944), a team of school attendance officers set up (in 1946), and penalties for contraventions of compulsory school attendance established.

The most recent developments in legislation occurred in 1974 when a new Education Act established free and compulsory education for all children from 6 to 16.years of age. The Act gave full powers to the Minister of Education to refuse the work permit to those who were below the compulsory school attendance age. The 
Minister of Education was also responsible for the regulation of the employment and conditions of work of such children as were permitted to work before the statutory age of 16 . Such regulations included the keeping of registers and the inspection of premises. The Department of Labour, together with welfare officers, were to help the Minister of Education in the task of enforcing the provisions of the Act. The 1988 Education Act merely restates the position on child employment adopted by the 1974 Act, and in one way is a step backwards, since it reduces the fines for contraventions established by the previous act. At the same time, however, Malta formally ratified the ILO's Minimum Age Convention No 138 of 1973 (Industry Today, 1988, p.47).

The problem of child labour has re-surfaced as an issue over the past few years, when a series of tragic accidents involving minors at work raised public consciousness and anger. Articles about child labour appeared in a number of publications locally, and while most of these brought forward little proof regarding the extent of the problem, media coverage was extensive enough to draw the attention of the relevant political, civic and ecclesiastical authorities of the islands. A number of public officials were interviewed by press reporters, and parliamentary questions were asked on the subject.

Thus, for instance, the Director of Work was reported as saying that while inspections were made on a regular basis, he did not have enough staff available to do the job thoroughly (il-Gens, 24/8/1990, pp.1,4). The Minister of Social Policy pointed out in Parliament that inspections to check child labour practice were being intensified, and that 7 children were found to be working in 1984, another 7 in 1985 , 11 in 1986, 12 in 1987 and 16 in 1988 (it-Torca, 12/8/1990, p.16). 30 cases were reported in 1989 ( $I l$-Gens; $24 / 8 / 1990$, p.4). The data presented in this study shows the extent to which the problem of child labour can be underestinnated.

\section{Factors influencing the extent of child labour.}

Schildkrout (1980, p.480) argues that in order to better understand the nature and extent of child labour, one needs to look closely at the specific economic, cultural, and social contexts in which it occurs. Child labour seems to prevail in competitive, highly volatile and seasonal markets where "it is more advantageous to employ children than adults: they can be easily Laid off when business is slack; they cost less; and they have no rights as workers and cannot join trade unions' (Bequele and Boyden, 1988, p.153). Due to legislation and to the setting up of international standards, child labour is least apparent in large-scale and modern industrial establishments. Here, "the high level of capitalisation, advanced technology, and an abundance of a relatively mobile adult work force, are all factors which militate against the continued employment of children' (Schildkrout, 1980, p.379). Child labour is consequently more prevalent in small and marginal factories where their size and underdeveloped technical sophistication renders them uncompetitive with the larger industries, which fact can drive them to resort to child employment to keep the wages low. Typicaliy such industries are textiles, clothing manufacture, food processing and canning (Unesco Courier, 1973, p.7).

The practice of employing children is most pronounced in those unregistered and undercapitalised enterprises which require casual labour, in that informal sector where it is very difficult for legal enforcers to supervise and control labour standards adequately. Thus, child labour is very common in small-scale and cottage industries, handicraft workshops, small retail shops, hotels, restaurants, services, street trades and domestic service, and agriculture. 
The economic and socio-cultural context in Malta encourages the practice of child-labour in a number of ways. One of the key industries in Malta is characterised by its seasonal nature. In 1986, for instance, earnings from tourism amounted to about $22 \%$ of all earnings from exports of goods and services, but the major part of these earnings were made during the summer months (Briguglio, 1988, pp.20-1). The seasonal nature of this industry encourages the employment of labour which can be easily shed: as we shall see, children are easily tempted into this sector. A second characteristic of the Maltese economic structure is the fact that the most common type of industrial set-up is the small firm. In 1987 for instance, $88.5 \%$ of workers in manufacturing, quarrying and construction and non-manufacturing industries were to be found in establishments employing less than 20 people (Central Office of Statistics, 1988, p.200). 75\% of all establishments employed 5 persons or less each. Again, in view of what has been said above, such establishments strive to remain competitive by employing casual and cheap labour. Many of these enterprises involve members of the same family.

A third economic characteristic is a highly developed "underground economy". Delia (1987) has estimated that the hidden economy in Malta could be as high as 10 $-20 \%$ of the GDP. Money earned through this kind of activity is, obviously, not declared or even invested in banks out of fear of raising suspicion. This partly explains why a large percentage of the currency is held in circulation: $50 \%$ of GNP in 1985 , compared to 5-10\% in many other countries in the same year (Briguglio, 1988, p.94). Needless to say, such 'underground' economic activity attracts those who, like students, prefer to work in establishments which, by their very nature, are hidden from the public scrutiny of the Labour Office. Finally, as Cremona (1989, p.3) notes, the fact that until recently Malta's tax rate was the highest in Europe, but its wage rate one of the lowest meant that parents were pressurised into one or other or both of the following strategies: seeking a second job in the underground economy to boost income, and/or rely directly or indirectly for financial help from the wages earned by their children.

There also socio-cultural factors which encourage child labour practices in Malta. One such factor which is peculiar to Malta is the adoption, since 1978, of a student-worker scheme for students at sixth form and University levels, i.e for ages 16 onwards. Based on similar attempts in other socialist countries such as China and Cuba to link productive work with education (Camoy and Samoff, 1990), this scheme (see Schembri 1982) gave a certain degree of legitimacy to the idea that students who were at school could - and indeed should - work. While perhaps few understood the ideological underpinnings of such a scheme, it is here postulated that it certainly did not discourage the idea - and perhaps actually encouraged the practice - of child labour. A second socio-cultural factor peculiar to Malta and which needs to be highlighted is the competitive work ethic which is ingrained in children from an early age. Even at a primary school level, Falzon and Busuttil (1988) report that $70.7 \%$ of students in state schools had attended private tuition after school hours. The percentage was even higher at a secondary school level, where $82.9 \%$ said that they attended private lessons over and above their schooling. Leisure for leisure's sake is strangely missing or severely curtailed for children in what is, for tourists, a leisure island. It would appear that if students are not labouring away in the catering or manufacturing industries, they are to be found busily employed striving for better grades or more credentials to ensure survival in the official labour market. 


\section{Contemporary research on child labour in Malta.}

Two empirical studies have been carried out regarding the extent of child labour practice in the Maltese islands. The first study by the present author focuses on participation in paid employment on the part of all third year Trade School students (age $=15$ years) on the main island of Malta. The second study, that carried out by Cremona (1989), focuses on all secondary level students in their last three years of compulsory schooling (ages $=13$ to 17 years) on the smaller island of Gozo. Both research projects are of a statistical nature and further research needs to be done to. explore, through qualitative means, the phenomenological significance of this work for minors (see Sultana, 1990 for an example).

With regards to the study carried out by the present author, a questionnaire form was distributed among all the third year trade school students found in their classrooms during the survey period between October and Decernber of 1989.680 students (male $=486$; female $=194$ ) were present to answer the questionnaire. ${ }^{5}$ A second study by Cremona (1989) reports on questionnaire data collected from 905 Gozitan students (male $=434$; female $=471$ ) attending the last three years of academic and technical secondary schools. While Cremona's research offers less details than that provided by the Trade School Research Project, it is useful in that it shows that similar patterns of child labour exist in Gozo as in Malta, and that participation in paid employment on the part of minors differs depending on whether they are in academic or technical schools. Different aspects of the practice of child labour in Malta will be explored in the sections below. Reference to Cremona's findings will be made throughout in order to highlight similarities and differences between the archipelago's two main islands.

\section{Malta's twilight economy}

Starting first with data which emerged from the Trade School Project, 378 students - or over $55 \%$ of those who responded to the questionnaire - said that they had worked for money at some stage or other in their life. 330 of these were male students; in other words, almost $70 \%$ of those attending boys' trade schools have worked. Only 48 female students, or close to $25 \%$ of the total number of girls sampled, admitted to having worked either in term time or during the holiday seasons. Of the total 378 students who worked, 203 did so before and/or after school hours, and on weekends in term time. 341 students worked during the holiday season, and 166 students worked both during term time and during holidays. Cremona (1989) reports similar patterns for his study of young people in Gozo. Thus, $46.8 \%$ of Gozitan boys and $16.4 \%$ of Gozitan girls were engaged in some form of waged employment. The lower percentages in Cremona's study are probably due to the fact that his sample included students attending both trade and technical schools as well as modern secondary and junior lyceum schools. In the latter, more academic oriented institutions, students were found to be less involved in paid employment, and this reduced the global percentage of working children.

The Trade School questionnaire reveals that students had started working before their fifteenth birthday. Indeed, 20 admitted that they had entered into paid employment at the age of ten or younger, while 10 and 33 had started working at the age of eleven and twelve respectively. 76 students had started working when they were thirteen years of age, and 130 when they were fourteen. Only 79 students admitted to having had their first work experience at the age of fifteen and over. A similar pattern emerges if we examine the data presented by Cremona for his sample of Gozitan students, In this case, while there were a few who began work at 6 or 7 years 
of age, the majority entered into some form of paid employment at the age of 12 $(15.8 \%), 13(17.2 \%)$, or 14 years of age $(21.7 \%)$,

It needs to be pointed out that for a number of reasons the statistics regarding the extent of involvement in the twilight economy are conserva tive ones. In the first place and with reference to both studies, it was clear that some students preferred to withhold information out of fear of being caught out by the authorities. They were quite aware that they were not entitled to work without a work book and the permission of the Minister of Education. A second reason which suggests that the statistics are in fact higher is that both questionnaires measured only 'paid employment'. From other research I carried out with the students in trade schools (Sultana, 1992), it is quite clear that girls, for instance, are often involved in carrying out domestic chores - such as taking care of younger children and doing housework which are either remunerated by "pocket money" allowances, or not at all. It will be argued that such activity has an economic function as it often releases adults so that these can work, or reduces the need for such adults to employ domestic help. Finally, and again with reference to my research, $42.5 \%$ of trade school students were missing from their classroom during the survey months. A study by Scicluna Calleja et al. (1988) found that girls in trade schools, on average, absented themselves for 50.5 out of 148 days, an absence rate of $33 \%$. The frequency for boys stood at 35 days out of 148 , yielding an absence rate of 24 . For the academic year $1987-88$, the Department of Education had approved 861 request for permission to leave school before 16 years of age (cf $I t$-Torca, 12th August, 1990, p.17). Both the high rates of absenteeism and early school-leaving are a sign of the readiness these students have to work, in the first case without, in the second with a work permit.

It is instructive to compare the Maltese and Gozitan data with those emerging from other studies carried out in parts of England and Scotland. MacLennan (1980) for instance found that 20 to $30 \%$ of all 14 to 16 -year-olds were in part-time employment in the United Kingdom. Finn (1984) reports that 75 of his sample of 150 boys and girls in their last year of compulsory schooling in 3 Coventry and 1 Rugby school had had some involvement in the juvenile labour market. Griffin (1985) found that $50 \%$ of her Bimingham girls had experienced some form of part-time employment prior to leaving school. Howieson (1990) reports that 45\% of a sample of school-leavers in Scotland had done part-time work during term time. The first three studies mentioned above confirm the patterns of child employment that have been found locally. In other words, more of the 'non-academic' students tend to be working than 'academic' ones, and more boys than girls tend to be in paid employment. Howieson, however, reports a different pattern. Howieson's study, which involved $10 \%$ of all school-leavers from 1979-1987, found that more girls $(67 \%)$ than boys $(41 \%)$ had worked, and that while the highest percentage of working students was to be found among the middle-attaining pupils (34\%), a higher proportion of the most academic pupils had a part-time job (29\%) than the least academic (25\%). Howieson is the only one to report on data collected longitudinally, and it is interesting to note that the number of students who did part-time work increased between 1979 and 1987.

It is also important to ask why students work. It is commonly believed in Malta that trade school students seek to work in the trade that they intend to practice after they leave school. My research however does not bear this out to any large extent. Of the 341 students who worked during the holiday season, only 43 - or $12.6 \%$ were employed in a sector where they could practice the trade skills they were learning at school. The percentage is almost twice as high for the group of 203 
students who worked during term time: 49 out of 203 students - or $24.1 \%$ - were therefore involved in work which could help them make progress in the skills they were studying at school. In another question, students were asked to identify what they liked about the work they did. 28 said that learning a trade was a positive aspect of their experience in paid employment. Despite this, there is agreement with Bequele and Boyden (1988, p.156) who, reflecting on child labour. within an international context, conclude that 'ILO studies give little reason to believe that working children are gaining valuable skills and experience. The vast majority receive little or no preparation for the work they are given and consequently child labour tends to be concentrated in unskilled, simple jobs that offer little opportunity for moving to better paid, safer or more interesting jobs'.

The major reason for working was undoubtedly related to financial remuneration. The highest number of students $(n=38)$ who expressed directly what they liked about the work they did during term or holiday time mentioned 'money' and 'pay'. Cremona $(1989, p .60)$ notes that $35 \%$ of the boys and $32 \%$ of the girls in his sample of Gozitan students had remuneration in mind when they decided to work. $44 \%$ of the girls and $25 \%$ of they boys said they were pushed to work for 'family reasons", which Cremona interprets as helping out in family business or in augmenting the family budget. Child labour, both within the house and outside of it, and whether it is formally remunerated or not, should therefore be considered as an economic contribution to the household economy rather than for any educational experience that it might offer. This economic contribution is made in both direct and indirect forms. In the first instance, the Trade School questionnaire revealed that 145 out of the 378 students or $38.35 \%$ - who worked throughout the year gave a percentage of the money they earned to their parents. Secondly, the fact that these young people were eaming money meant that parents were not obliged to provide allowances to support expenses on clothes, travel, food, and entertainment and leisure activities. Some of these young people were therefore financing most if not all of their own leisure activities, besides helping out their parents.

It has been noted in a number of countries that the economic recession and high rates of unemployment have put even greater pressures on young people to contribute to the farnily budget (see Finn, 1984; Sultana, 1990a; Howieson, 1990). While Malta has not gone through the same kind of economic problems and there is a highly developed social service system, it is postulated that high taxation levels, relatively low wages, and the current increases in cost-of-living will have very much the same effect, and that parents actually encourage their children to find some form of paid employment. This proposition is borne out by the fact that $41 \%$ of the students who replied to the trade school questionnaire admitted that they had found their jobs with the help of parents; older siblings, or uncles and aunts.

Finally, it should be noted that work provided students with the possibility of socialising. 26 trade school students mentioned this factor as a pleasant thing about their work experience: meeting members of the opposite sex, tourists, and making friends with adult workers provided them with positive experiences. It became clear from my study that many students were working in jobs which allowed mixing with older workers. While 79 students claimed they worked with persons of their own age, 248 said that they did not. Work during term and holiday time to some extent also encouraged the mixing of genders: while boys and girls were involved in work roles which generally revealed the sexual division of labour in Malta, 181 worked in a mixed sex environment, while 148 were in a single gender workplace. Working 
alongside adults of the same or different gender can have both positive and negative effects on young students. Among the latter one can mention the tendency on the part of full-time, non-seasonal adult workers to impute a lower status on younger, casual labourers (cf Clark, 1986). Sexual harassment is also often reported when adult males work alongside younger females (Sultana, 1990a).

\section{The nature of employment performed and its remuneration.}

The range of jobs reported in the Trade Schools Project questionnaire was very wide indeed. Most, however, were involved in work in an informal sector which afforded them little educational experience and practically no useful training for adult work roles other than 'conditioning' to form part of an unskilled, uneducated proletariat. Among the most common jobs done by the 203 students who worked during term time were assisting in shops, helping out in a variety of small-sized trade enterprises involving work in carpentry, electrical installation, and mechanical repairs of cars. Others were employed as farmhands. Before and after school hours as well as during weekends students cleaned wood, helped builders and butchers, acted as salespersons, polished wood, sprayed wood and cars, worked in kitchens, painted houses, and sold produce. If we had to group these different jobs into larger categories, the top three work categories for term time jobs would be as follows: Trades $(n=64)$; Catering ( $n=42)$ and Shop Attendance $(n=32)$.

Similar patterns can be found in the jobs done by students during holiday time. Some of the more popular jobs were, again, helping out in small trade establishments. Student summer work also consisted of street vending, tile laying, painting houses, shop assisting, and working in hotels and other catering establishments as waiters or waitresses, barmen or barmaids, pool attendants, beach attendants, take-aways, kitchen hands, cleaners and maids, and confectioners. If we again grouped the jobs into categories, summer time work would have the following profile: Catering $(\mathrm{n}-130)$; Trades $(\mathrm{n}=100)$ and Shop Attendance $(\mathrm{n}=26)$. It is indicative that during holiday time, 17 students were involved in some form or other of factory work. Gozitan students were employed in similar kind of work, and Cremona (1989) reports a concentration of children in the catering sector - which employs $29 \%$ of all male children who work - in work related to shops. $30 \%$ of Cremona's female sample were involved in home-based knitting work for the textile industry.

It is important to point out that trade school students, for instance, were involved in work which has been specifically designated as dangerous By ILO Convention No. 138 , and which could not be excluded from the Covention's application. If we take into account all stadent work done during term and holiday time, these included quarrying ( $n=2)$, electrical works $(n=18)$, construction $(n=22)$ and transport and storage $(n=5) .8$ students worked in a factory during term time, while 17 did so during the holiday season. A number of ILO conventions on work done by minors have been careful to specify that some employment - such as work in restaurants and in bars - present particular problems for the moral safety of young persons. It is therefore relevant to point out the large numbers of students employed as barmen/barmaids, and as waiters/waitresses. This reflects the importance of the tourist service sector in the overall Maltese economy, as well as nature of this sector characterised by the 'reed' for cheap labour that can be easily employed and shed.

A general point that can be made about the kind of jobs done by these young workers is its reflection of the different destinies in the sexual division of labour. Hence, in both the Maltese and Gozitan studies, girls tended to be found in what are 
locally considered to be traditionally female jobs such as cleaning, tailoring, hairdressing and baby-sitting. Another fact that needs to be highlighted is the large number of students employed by their adult family members. Of the 196 trade school students who replied to the question asking for details regarding employers, 62 - or $31.6 \%$ - answered that employment was provided by a family member. Cremona (1989) found a similar pattern for his sample in Gozo, and reports that 104 children work for their parents, while 30 were employed by somebody related to the family. As in many other areas in the world, children often work in familial contexts (Bequele and Boyden, 1988, p.158).

A high percentage of trade school students reported that they helped out their parents in household chores. While this is not often seen to be work, Schildkrout $(1980, p .484)$ is correct to point out that children are clearly economic assets since when they perform errands they are 'contributing to the maintenance of their households, as well as reducing the opportunity cost of women's [and men's] work, even though children may not be directly generating income'. In other words, were students not to perform these tasks, other help would have to be employed. It is also possible that children's work may release one or other or both of the parents for productive employment in a full-time or part-time capacity.

On average, Trade school students involved in term-time employment worked an average of 4.7 hours' work per day. While female students worked 4.6 hours dally. It needs to be pointed out that these averages conceal the fact that 16 students did 6 hours work daily, 12 did 7 hours work or more per day, and 18 laboured between 8 and 11 hours daily. Cremona $(1989$, p.54) reports that most of the Gozitan male and female students worked less than 10 hours per week during term time.

The average number of hours of work for students involved in holiday work was almost twice that for term time jobs. Male and female students worked, on average, 8.4 hours per day, with males clocking up 8.6 hours and females 7.01 hours daily. Again, averages conceal the fact that 47 students worked for 9 hours daily, 33 for 10 hours, 16 for 11 hours, another 16 for 12 hours, 3 for 14 hours, and 5 for 15 hours per day. Similar data was reported by Cremona $(1989$, p.53) with regards to Gozitan students: $22.2 \%$ of his sample of boys who worked during the holiday season laboured for between 31 and 40 hours per week, while $16.8 \%$ worked between 41 and 50 hours. $23.4 \%$ of the girls worked for 10 hours or less per week, while $19 \%$ of them worked between 41 and 50 hours per week. Fewer gills than boys worked more than 70 hours per week during the holiday season.

The Trade School questionnaire data permits the calculation of the average hourly and weekly wages that these students received, although it does not permit the identification of cases where there was a combination of cash and kind as remuneration. There is an important degree of difference between the average hourly rate of pay for term and,for holiday jobs. For the former, the average was Lml.18c per hour, ${ }^{6}$ with a difference of five cents between the average hourly pay for males and for females, in favour of the former. The average conceals the fact that 83 of the students who worked during term time did not know their hourly rate of pay - this, it will be argued later, enhances the employers ${ }^{*}$ possibility of exploitation of young workers. It is possible that flexible hourly rates of pay is a characteristic feature of the informal sector in which most of the students laboured.

The average hourly rates received by trade school students also hide the fact that some students were getting far below the Lml.18 $\mathrm{c}$ mentioned above: 18 were getting only between $25 \mathrm{c}$ and $50 \mathrm{c}$ per hour; 26 were eaming between $55 \mathrm{c}$ and $80 \mathrm{c}$ an hour. 
Other students were earning more than the average: 15 were earning between $\mathrm{Lm} 2$ and $L m 2.50 \mathrm{c}$ an hour, 3 were earning $L \mathrm{~m} 4$ and 2 were earning as much as $L m 5$ per hour. On average, the weekly earning for males who worked during term time was $\operatorname{Lm} 23.20 \mathrm{c}$ while for females the figure was Lm18.

Holiday work earned students even less money, below the $86 \mathrm{c}$ per hour which constitutes the official minimum wage in Malta. On average, an hour's work gave trade school students between $67.9 \mathrm{c}$ - if they worked five days a week - or $56.6 \mathrm{c}$ - if they worked for six days a week. This meant that most students were eaming between $L m 30$ and $L m 50$ a week ( $n=122$ ), while a minority were earning between Lm55 and Lm70 a week ( $n=14$ ). Five students were earning Lmlo0 per week in the holiday season. It needs to be noted that while the average weekly earnings for holiday work are higher than those for term time, students were involved in work for much longer hours. Cremona provides similar information, although it seems that Gozitan students are even more underpaid than Maltese students. Cremona $(1989$, p.55) notes that $52.5 \%$ of his respondents were earning between $51 \mathrm{c}$ and $\mathrm{Lml}$ per hour, while $27 \%$ were earning less than $50 \mathrm{c}$ per hour.

\section{The experience of work.}

One needs to look beyond wages to have a better understanding of the exploitative conditions under which child labour is usually carried out. With regards to remuneration, both Cremona's study and mine indicate quite clearly that young persons are satisfied with very little: Cremona (1989, pp.56-57) notes that only $25 \%$ of the girls and $12 \%$ of the boys claimed that their wages were low for the type of work they performed; $47 \%$ of the work they were doing after they left school. 50 students said that they felt that they were "happy" and were 'good' at what they were doing. 19 were keen to remain in the trade they were practising, while another 19 believed that they were making enough money in that job as to warrant their staying on. 9 felt that their job offered them opportunities to socialise, and they felt accepted and respected at work, while 4 mentioned that their particular job did not cause them any physical stress, and therefore they found no reason to leave it on reaching compulsory school-leaving age. Whatever the reason, it is significant that so many students did not desire - possibly not even foresee the possibility of - a better working future with improved conditions of work, better salaries, and enjoying more rights and/or responsibilities.

Cremona's data is limited when it comes to providing information on the Gozitan students' experience of work. The latter were simply asked to say whether they thought their conditions of work were good or not without actually providing any indication of the specific conditions in question. In his sample (Cremona, 1989, p.58), $62 \%$ of the boys and $49 \%$ of the girls claimed that their conditions at work were good; $30 \%$ of the boys and $39 \%$ of the girls said the conditions were fair, while $4 \%$ of the boys and $5 \%$ of the girls admitted that the conditions were bad. Again, it becomes apparent that these students were basically satisfied with their work experience, and were largely unaware of the exploitative conditions they were labouring under.

\section{Child labour and schooling.}

Childhood and youth, as Tucker (1977) among others has pointed out, are not mere biological constructs. They are also, and perhaps above all, projections of particular historical social formations. What appears at one point in time to be atrocious or totally unacceptable can be found to be common practice at another point in time. 
Suchadolski (1979, p.37), a Polish philosopher who has published extensively on the question of the rights of the child, notes that According to their circumstances, children in the past experienced either the joy of a carefree existence with plenty of opportunities for play in the fresh air, or a life of hardship and struggle characterised by poverty, homelessness, dependence on private persons, charitable institutions and even the State, and employment in adult work, which resulted in the exploitation and premature death of the children who made up this cheap labour force'. Reflecting on the status of the child today, Schildkrout $(1980, p .484)$ argues that in many societies, children's economic contribution is insignificant, and 'childhood is defined as the very antithesis of work Childhood is assumed to be a rehearsal for adult life, and chilthood experiences are then evaluated in terms of their educational importance'. It is therefore in the context of education and schooling rather than of labour and work that children develop and grow in modern social formations.

There are a number of relationships that can be played out between child labour and schooling. It could be concluded from Schildkrout's excerpt above that there is value in child labour when this offers educational experiences to children. This proposition has taken hold in a number of countries, and secondary schools in countries as far apart as the United Kingdom, Australia and New Zealand actually organise work experience or work exploration placements for their students so that these can learn about the world of work (cf Watts, 1983). The educational value of such programmes is doubtful (cf Sultana, 1989), especially since the sector in which students are placed often reinforces the social and sexual division of labour, reproducing class, racial, ethnic and gendered economic destinies. Besides, it has already been pointed out in a previous section that many of the tasks performed by students are relatively simple and allow little opportunity for learning.

Earlier it was argued that one of the most successful ways of controlling child labour has been the raising of compulsory schooling to the age of fifteen or, as in Malta, sixteen. The presence of an educational infrastructure which can cater for all students up to a given age does not of course guarantee the complete disappearance of child labour. In the first place, as we have seen, many students are involved in part-time and full-time work during school holidays. Secondly, a large number of students manage to combine schooling with work by labouring before or/and after school hours and during weekends. Others simply do not turn up at school and prefer to work. All of these options have definite and negative effects on students" performance at school. Students begin associating schooling with loss of earnings, and this drastically reduces the little motivation there might be to invest in education. This process is bound to happen if, as Willis (1977) and Sultana (1990b) suggest, students from a working class background somehow penetrate the credentialling ideology and perceive that schooling will have little if any relationship between investment in schooling and future employment prospects.

When work is cartied on outside school hours, the result is exposure to fatigue. Bequele and Boyden $(1988$, p.157) draw on a number of studies and report that 'Grossly overworked, the children are found to be less alert, less ardwous and less regular in school attendance, and consequently are at a constant disadvantage throughout their school years and even later'. School work should indeed be considered to be work for a number of reasons. Qvortrup $(1989, \mathrm{p} .10)$ correctly argues that from a historical perspective, 'school work is child labour under modern conditions. The social importance of children's school work is just as great as child labour was for parents and the local community in former times. Over and above 
this, political economy of education after Bowles and Gintis (1976) stresses the correspondence between school and work, arguing that school children experience a number of the social relations of production - including, for instance, the bifurcation between the spheres of work and leisure - at school (cf Apple and King, 1977; Cole, 1988; Sultana, 1990c). Indeed, if one adopts a structuralist and conflict perspective, and if one accepts the premises behind the 'correspondence theory', one could well argue that it is quite enough that young people are exposed to the hierarchical and alienating social relations - typical of capitalism - within the school. To allow the reinforcement of such relations within a context of labour would only serve to further humankind from fulfilling one of its most basic duties, namely offering "the child the best it has to give'(Declaration of the Rights of the Child, United Nations, November 1959).

\section{Policy recommendations.}

One important step towards the achievement of that goal is the formulation of a strong policy which ensures that the rights of the child for education and for freedom from material constraints are guaranteed. Such a policy would also ensure that children will no longer need to labour - at least not in situations which permit exploitation. To summarise a number of points argued throughout the paper, a strong and effective policy with regards to child labour is necessary because, in Malta as elsewhere:

- Children are involved in doing repetitive, alienating and fragmented tasks, having little or no control over the work process, and learning and using few skills. These unskilled and often simple jobs offer little opportunity to move on to other, better paid, safer or more interesting occupations. Children are therefore often trapped in fluctuating or unstable labour markets characterised by low pay and insecurity of employment.

- These working children have few rights, and the few they do have are not clearly stipulated. They are thus more subject to the whims of their employers.

- Their vulnerability is emphasised by the fact that they have no collective representation and thus little protection from exploitation or harassment. The fact that they are voluntarily working illegally means that they will be even more hesitant to complain to authorities as this would mean admitting to having broken the law. They have few alternatives for employment, and this fact renders them even more dependent on their employers.

- Children are often expected to do adult work for a wage far below that normally given to adults, even when they are involved in doing the same tasks. There are no fringe benefits, insurance or social security costs. Such low wages give employers an advantage in national - and in some cases, international markets. In addition, these employers can often avoid the obligation to comply with rational employment requirements.

- Employers do not generally take into account that most workplaces and most work tasks were designed with adults in mind. Hence, when children perform the same work they are more likely 'to stuffer occupational injuries due to inattention, fatigue, poor judgement or insufficient knowledge of work processes and also to the fact that the equipment, machinery, tools and layout of most workplaces are designed for adults' (Bequele and Boyden, 1988, p.154) 
- These children are involved in long hours of work,especially if we consider school to be work. Many labour on through the weekends, attracted by the added incentive of special rates of pay.

- It is moreover not often pointed out that more remotely; but perhaps very importantly for the employing class, child labour seems to initiate students into capitalist work relations and conditions, enveloping young people in a world of hard facts where the 'what is' assumes a common-sense and taken-for-granted quality, divorcing it from the alternative and humane vision of the 'what could' and the 'what should' be. Experience in the twilight economy therefore seems to mould young persons into the future workers who will find naive joy in the 'improved' conditions of their full time work. Such an experience produces ideas, feelings, desires and forms of consciousness which lead to an adaptive mentality rather than to one which yearns - and struggles - for altemative arrangements in the social formation.

What form would a child labour policy take in view of all that has been said thus far? Swepston (1982, p.590) notes that a key factor is enforcement, and that this depends on three basic requirements: first, the identification of the persons responsible for compliance; second, the establishment of enforcement measures, including penalties, and third, the keeping of registers of young persons employed or working. $\mathrm{He}$ concludes (ibid., p.591) that 'the most indispensable enforcement mechanism in this field is an adequate labour inspection service.

I would however tend to agree with Bequele and Boyder (1988, p.163) when they note that legislation and enforcement on their own have their disadvantages in that they can force children to 'work clandestinely in unregulated sectors of the economy where it is impossible either to detect or to protect them'. They therefore favour a multi-pronged approach which includes legislation and law-enforcement, but goes beyond that to embrace action in areas such as incomes and employment, formal and informal education, welfare and the promotion of children's rights. They also highlight the role that unions can play by including young persons in their struggle to improve, if not change, the social relations and conditions of labour.

Bequele and Boyden (ibid., p. 163) also note that incentives are also effective in curbing the incidence of child labour. The authors present Hong Kong as an example of a country which has developed an efficient and diverse approach which goes beyond legislation. This includes regular and thorough inspections; yearly special campaigns to detect child employment and to raise public awareness; requiring all young workers to have an identification card with photograph which facilitates inspection and enforcement of rules; and the introduction of social security contributions in respect of young workers. The latter fact has reduced employers' reliance on child labour in that country. Depending on the resources of a country, there could be the payment of a cash allowance for children withdrawn from prohibited employment:

Educators too have a part to play. Transformative teachers intent on engaging the world in order to change the oppressive conditions in which life is lived need to help students develop.a critical social intelligence, enabling them to penetrate the structures of domination and injustice in which they already live in a multiple of social sites, and most of all at work. Such teachers would develop a critical literacy (Freire, 1972 ) in their students, who would thus be able to read and decode not only 'words' but 'the world'. It is only by awakening in these students a full consciousness of the 
extent of their exploited condition that they will prove willing to co-operate with those who are struggling in their behalf.

\section{Notes}

1. Malta is made up of a group of small islands, two of which are inhabited. The larger island, Malta, has a population of around 325,000 while Gozo's population is around 25,000 . The archipelago of islands covers a surface area of about 316 square kilometres. It "enjoys" a strategic position in the Mediterranean, lying 93 kilometres to the south of Sicily and 290 kilometres to the north of the African coast. Its position in the middle of the Mediterranean and its natural harbours have invited a number of colonial powers, including the British, to take possession of the islands. Malta obtained its political independence from Britain in 1964, and was deciared a Republic ten years later.

2. Trade Schools were set up in Malta in 1972, and in 1989 they were catering for 2868 boys and 1509 girls, or about $17.5 \%$ of all secondary school students attending government schools (Central Office of Statistics, 1990).

3. These definitions are to be found in the various conventions of the ILO regarding minimum age for employment (cf Swepston, 1982 for an overview of the various conventions passed at International Labour Conferences since 1919).

4. Among these are the following: Labour Post, a publication of the local General Workers' Union (March, 1988 and January/February 1989), il-Gers (24th August, 1990), a publication of the Catholic Church; it-Torea, a weekly publication of Malta's General Workers' Union (12ib August, 1990); it-Haddiem, a publication of the Young Christian Workers' Organisation (June/July, 1990); and Altemattiva (November, 1990), a publication of the Green's political movement.

5. This represents $57.53 \%$ of the total of 1182 students (male $=725$; female $=457$ ) that should have been present according to official lists of population in trade schools for $1989 / 1990$ (Department of Education, July 1990). Students not present were generally habitual absentees, with the exception of 6 male students who were involved in an extra-curricular project and were absent from school for long periods of time, and 1 male who preferred not to fill in the questionnaire.

6. The minimum wage for a forty hour week is $\operatorname{lm} 34.37 \mathrm{c}$. Depending on fluctuations in exchange rates, one Maltese lira is equivalent to around 2.5 ECUs (or 3.35 U.S. dollars).

\section{References}

Alternativa. 1990. ' Child labour f'Malta: Fatti' (November).

Anti-Slavery Society. 1989. Anti-Slavery Reporter, 13(5)

Apple, M. and King, N. 1977. 'What do schools teach?', Curricutum Inquiry, 6(4).

Bequele, A. and Boyden, J. 1988a. Combating Child Labour (Geneya, MLO).

Bequele, A and Boyden, J. 1988. 'Working children: Current trends and policy responses', International Labour Review, $127(2)$.

Bingham, C. 1990. 'The child-labour sting', Newsweek, March 26.

Borg, R. 1983. Developments in Maltese industrial law. Unpublished LLD thesis, University of Malta.

Bowles, S. and Gintis, H. 1976, Schooling in Capitalist America. London, Routledge and Kegan Paul.

Brigulgio, L. 1988. The Maltese economy: A macroeconomic analysis. Malta, David Moore Publications.

Busuttil, S. 1965. 'Malta's economy in the nineteenth century', Journal of the Faculty of Arts, $3(1)$.

'Camoy, $M$. and Samoff, J. 1990. Education and social transition in the third world. Princeton, Princeton University Press.

Central Office of Statistics. 1988. Abstract of Annual Statistics. Valletta, Malta, Govemment Press,

Central Office of Statistics. 1990. Education Statistics: 1988- 89. Valletta, Malta, Govemment Press.

Cole, M. (Ed.) 1988, Bowles and Gintis revisited: Correspondence and contradiction in educational theory. Lewes, Falmer Press. 
Cremona, J. 1989. The underground economy in Gozo The case of child workers. Unpublished B.A.(Hons.) Public Administration disssertation, University of Malta.

Courier (UNESCO). 1973. ' 40 million child-workers in the world today', October.

Delia, E. P. 1987. The task ahead - Dimensions, ideologies and policies: A study on the state of the Maltese economy, Malta, Confederation of Private Enterprise.

Falzon, P. A. and Busuttil, J. 1988. Private tuition in Malta: a hidden educational phenomenon revealed. Unpublished B.Ed,(Hons.) dissertation, University of Malta.

Finn, D. 1984. 'Leaving school and growing up: work experience in the juvenile labour market. In I. Bates et al, Schooling for the dole: the new vocationalisn. London, Macrillan.

Freite, P. 1972. Pedagogy of the oppressed. Harmondsworth, Penguin.

Fyfe, A. (1989) Child Labour, Cambridge, Polity Press.

Gens. 1990. "Tfal li jahdmu", 24 August, 122.

Griffin, C. 1985. Typical girls? Young women from the school to the job market. London, Routledge and Kegan Paul

Haddiema. 1990. 'Kummerc bit-tfal f' Ghawdex", JunelJuly, No.20.

Howieson, $\mathrm{C} .1990$. 'Beyond the gate: Work experience and part- time work among secondary school pupils in Sootland', British Jotunal of Edtication and Work, 3(3)

Industry Today. 1988. 'ILO Conventions ratified byMalta', (August), p.47.

Labour Post. 1988. "The wordd-wide scandal of child labour", 49 (March)

Labour Post. 1989. 'The under-age proletariat', 54 (January/February).

Lavalette, M., McKechnie, J., and Hobos, S. (1990) The Forgotten Workforce: Scottish Children at Work, Scottish Low Fay Unit.

MacLennan, E. 1980. Working children. Pamphlet No.15, London Low Pay Unit.

Myers, W. E. (ed.)(1991) Protecting Working Children, London and New Jersey, Zed Books.

Qvortrup, J. 1989. "European childhood', Forum (1) Council of Europe.

Schembri, C. 1982. The development of the worker-student scheme in MaIta. Unpublished B.Ed.(Hons.) dissertation, University of Malta.

Scicluna-Calleya, $S_{s}$ Sultana, $R$. and Zamm!t, R. (1988) Absenteesm in Trade Schools. Unpublished report (mimeo), Department of Education.

Schildkrout, E. 1980. 'Children's work reconsidered', International Social Science Journal (UNESCO), 32(3).

Suchodoiski, B. 1979. 'Ethical aspects of the child's right to education' In G. Mialaret (Ed.) The chuld's right to education. Paris, UNESCO.

Sultana, R. G. 1989. "Transition education, student contestation and the production of meaning", British Joumal of Sociology of Education, $10(3)$.

Sultana, R. G. 1990a. 'Breaking them in? School kids in the twilight economy', New Zealand Journal of Industrial Relations, 15.

Sultana, R, G. 1990b. 'It's who you know, not what you know: Penetrating the credentialling Ideology', Brizish Journal of Guidance and Counselling, 18(1).

Sultana, R. G. 1990c. 'Schooling for work in New Zealand: Reproduction, contestation and transformation in three high schools', British Joumal of Education and Work, 3(2)

Sultana, R. G. (1992) Education and National Development;Historical and Critical Perspectives on Vocational Schooling in Malta (Msida, Mireva Press).

Swepston, L 1982 "Child labour: Its regulation by IIO standards and national legislation', International Labour Revew, 121(5).

Torca, 1990. '1l-haddiema tfal qed jizdiedu!' 12 August.

Tucker, N. 1977. What is a child? London, Fontana.

Watts, A. G: 1983. Work experlence and schools. London, Heinemann.

Willis, P. 1977. Learning to labour. Famborough, Saxon House. 